\title{
Credit-Bearing Information Literacy Courses in Academic Libraries: Comparing Peers
}

\author{
Spencer Jardine, Sandra Shropshire, and Regina \\ Koury
}

This article identifies variations that are within the credit-bearing information literacy (IL) programs of a group of similar libraries: Idaho State University's peer institutions that have been formally designated by the Idaho State Board of Education. This group of institutions shares two common characteristics - that is, they are public and are doctoral-granting schools-and vary in many others, according to Carnegie classification system data. Motivated by a desire to evaluate the current status of their own instruction program within the context of the university's official peer institutions, the authors gathered reported data from their peers and coupled these data with information from personal interviews with the coordinators of instruction at peer institutions. This method of collecting the data provided context for the interview questions that would follow and revealed nuanced qualitative ideas and issues such as best practices within this cohort. The process of scoping the study, identifying comparisons with peers and analysis of results, will be useful to other libraries making decisions about the impact and directions of their instruction programs.

\section{Introduction}

Academic librarians have long sought to deliver information literacy-based instruction in some form as a service to their patrons. The foundation for information literacy for-credit courses can be traced to 1881, when R.C. Davis pioneered the idea at the University of Michigan that they represent a long-term teaching and learning opportunity. ${ }^{1}$ In response to ideas such as these, academic libraries developed courses within their instruction programs that offer credit as a way to signal to students that IL is a skill worthy of their time and effort. The Association of College and Research Libraries' (ACRL) Instruction Section has taken the lead on offering guidance to instruction librarians to plan, develop, and assess libraries' instructional programs. ACRL sug-

Spencer Jardine is Coordinator of Instruction and Associate Professor and Sandra Shropshire is Associate University Librarian for Collections \& Special Projects, both in the Eli M. Oboler Library at Idaho State University; e-mail: jardspen@isu.edu and shrosand@isu.edu; Regina Koury is Director of the Paul Robeson Library at Rutgers University, e-mail: regina.koury@rutgers.edu. (C2018 Spencer Jardine, Sandra Shropshire, and Regina Koury, Attribution-NonCommercial (http://creativecommons.org/licenses/ by-nc/4.0/) CC BY-NC. 
gests conducting environmental scan surveys to determine how instruction librarians need to improve their instructional programs. Instruction programs are dynamic and many factors affect their ever-changing goals and needs. Major initiatives such as an institution's strategic planning, curriculum changes, and accreditation reviews greatly influence the instructional programs, services, and environment. ${ }^{2}$ The prevalence of those libraries offering credit-bearing IL courses differs broadly by size, type, and location and has varied over time. From broad-based, national-level studies, it is clear that the proportion of library groups offering credit-based IL has, at times, been as low as 19 percent and as high as 42 percent. Some studies of smaller groups of libraries with some degree of commonality reports the library offering of credit-bearing IL courses as a slightly higher range between 25 and 45 percent.

Of the studies available in the literature, none was found that provided a useful context for ISU Libraries to use effectively in evaluating its own credit-bearing IL program. It is a small library system in a sparsely populated state, and it is a library that is neither a consortia member nor an Association of Research Libraries (ARL) library. Because of this, natural peer groupings, such as those existing in consortia or in a statebased system, do not apply. Therefore, the ISU Libraries made the decision in 2015 to use the "peer" group that its governing body, the Idaho State Board of Education (SBOE), had designated. These libraries are all at doctoral-granting public institutions. The libraries in this group number 14; three aspirational peers have also been named. In addition, the authors added to the group the other two state, four-year, doctoralgranting schools that were not included in the SBOE's designated peer group for ISU. ISU would use this group to conduct a comparison of how officially designated peer institutions offered credit-bearing IL to their students as a way to evaluate its own efforts in this area. This would, it was additionally hoped, help the library in its growth as it sought to address university goals.

\section{Literature Review}

There are many aspects of credit-bearing IL that are discussed within the literature. Badke calls for IL to stand as its own discipline, complete with a specific range of foci that includes theoretical, methodological, and practical approaches. ${ }^{3}$ Best practices in developing, delivering, and assessing credit-bearing IL courses are treated by Hollister in his compilation of the ideas and thinking of current practitioners in the field. ${ }^{4} \mathrm{An}-$ other example considers the student perspective by studying and measuring student engagement in IL courses. ${ }^{5}$ Hrycaj examines syllabi for online credit-bearing IL courses as a way to gain an appreciation of the current state of 100 credit-bearing IL courses being offered at colleges and universities, without consideration of size or location. ${ }^{6}$

These studies assume, however, established programs of credit-bearing IL. Those interested in examining their own credit-bearing IL programs in the context of other, more established ones may benefit from an understanding of how credit-bearing IL has developed. The literature documents the historical and current state of instruction programs in U.S. academic libraries. Yearwood, Foasberg, and Rosenberg in 2015 discuss the results of a survey of librarians within the City University of New York (CUNY) system, asking them to identify the most effective forms of library instruction. Interestingly, instructor/student perception was not addressed. ${ }^{7}$ The low response rate $(18 \%)$ made drawing conclusions difficult, but responses suggest a clear preference from librarians for one-on-one research consultations, followed by credit courses in IL.

Cohen et al. offer the results of a wide-ranging 2014 survey of IL offerings in U.S. academic libraries. They note that most of the literature on credit-bearing IL is "either about teaching practices in individual courses or takes a broader look at the pros and cons of credit courses, especially as compared to embedded instruction." Drawn from 
a group of 3,814 institutions, the study is distinguished by its inclusion of private institutions. A 30-question survey was sent to a sample of librarians at 1,758 institutions. Among findings that report on the prevalence of common methods of IL such as instructor-requested, individual consultations and self-paced tutorials, the report also indicates that 19 percent of the responding institutions offer a credit-bearing IL course. ${ }^{8}$

Margaret Burke in 2012 discusses credit-bearing IL, specifically, and surveyed ACRL's Information Literacy Instruction listserv followers (ILI-L) to solicit their reports of how credit-bearing classes are being delivered at their institutions. The survey's premise assumes that credit-bearing IL is being offered, so results report on practical aspects of this type of effort, including assessment efforts, course development and philosophy, adjunct use, and more. ${ }^{9}$

Erin Davis, Kacy Lundstrom, and Pamela Martin conducted a 2011 survey of academic librarians who participate in library instruction by drawing on followers of three ALA-sponsored listservs whose readers are likely to be teaching librarians: ILI-L, COLLIB-L, and STS-L. Their findings dealt with these librarians' perceptions of their self-identity and their attitudes about the different "models" or methods of library instruction. Approximately 37 percent of the respondents offer for-credit courses. They observe of those who offer both integrated library instruction and credit-bearing instruction: "The majority of librarians who teach using both models appear to favor for-credit, however, and this opinion might hold more weight since it comes from librarians who have experience with both types of instruction." 10

Previous studies reveal the range of activities that have historically comprised the instruction efforts of academic libraries. With regard to the prevalence of credit-bearing IL offerings at a broad level, a notable study is the Library Orientation/Instruction Exchange (LOEX) repository-based study by Mary Butterfield. This is a Year 1 report of LOEX member activities in 1973, which shows that 22 percent of organizations offer credit-based IL courses. ${ }^{11}$ Others include Carolyn Kirkendall's 1980 work that cumulated LOEX data from 1974 to 1979 and showed that credit-based IL offerings are at 42 percent, ${ }^{12}$ and work by Teresa Mensching, who in 1989 covered 1987 LOEX activities and reported that 29 percent offer credit-bearing classes. ${ }^{13}$ Linda Shirato and Joseph Badics repeated in 1995 the Kirkendall and Mensching surveys and reported - among many other things - that 30 percent of LOEX members offered credit-bearing courses. ${ }^{14}$

Other surveys on instruction activities are smaller in scope and focus on groups of libraries that are similar in some way. Sue Phelps, Heidi Senior, and Karen Diller in 2011 surveyed Orbis Cascade Alliance members and found that 45 percent of these members offer credit-bearing IL courses. ${ }^{15}$ In 1988, Laura Windsor surveyed 52 college and university libraries and reported that 34.4 percent offer credit-bearing IL courses. ${ }^{16}$ A survey of ARL members by Barbara Wittkopf in 1991 revealed that 28 percent of members offer credit-bearing IL. ${ }^{17}$ In 1986, Susan Janney surveyed North Carolina community college libraries and reported that 25 percent of these teach credit-bearing IL courses. ${ }^{18}$ Jessica Hutchings and Malia Willey surveyed 47 colleges and universities in Louisiana in 2014 and found that credit-based IL course offerings are at 32 percent. ${ }^{19}$ Otis Chadley and Jacquelyn Gavryck looked at 72 ARL libraries in 1989 and reported that 33 percent of them offer credit-based IL courses. ${ }^{20}$

The literature offers a rich picture of prevalence of credit-bearing IL efforts that are underway at U.S. academic libraries. Other surveys are older and some limited in scope, but they may offer insight. Even so, no in-depth examination of a small group exists that would reveal motivations, local circumstances, and, ideally, guidance for a library looking to evaluate its own IL situation in the context of those present in institutions with similar characteristics. 


\section{The Credit-Bearing IL Program at ISU Libraries}

Idaho State University (ISU), a Carnegie-classified doctoral research and teaching institution located in Pocatello, Idaho, enrolls approximately 13,000 students annually. ISU offers more than 250 programs, such as allied health professions, natural and physical sciences, humanities, performing and visual arts, education, engineering, business, and technology. It operates three different campuses across southern Idaho, in an area that services approximately 3,500 square miles. Isolated in certain ways, the university is the smallest of three publicly supported universities in the state and is 220 miles from its nearest sister institution. Delivery of curriculum via distance is an increasingly important aspect of the university's teaching effort. As an academic library, the ISU Libraries support the institution's mission to foster student learning and discovery through teaching, research, and creative activity. To foster those skills, it is important to equip students with IL skills; to that end, the library instruction department's mission "is to help [students, faculty, and staff] learn to use library resources efficiently and effectively." ${ }^{21}$

The delivery of credit-bearing instruction by the ISU Libraries resulted from the efforts of many over a period of twenty years. One-shot library instruction workshops, conducted at faculty request, during a regularly scheduled class time and customized to meet needs of a particular class, have been offered at least since 1996. At that time, a bibliographic instruction librarian began efforts to raise awareness on an informal basis by speaking to deans, the faculty senate, and individual departments about the need for formalized information literacy instruction. The combination of workshop delivery and the informal efforts served to heighten awareness of the importance of information literacy.

In 2010, the Coordinator of Library Instruction proposed a one-credit IL course as an experimental course. The course received approvals from the library faculty, the Library Dean, and the University Curriculum Council (UCC), the elected, representative body of faculty that authorizes course offerings at the university. The experimental course was offered face to face and was taught by the Coordinator of Instruction in fall 2011. After one semester of teaching the course, the Coordinator saw that the time allotment for a one-credit course was insufficient for the delivery of the necessary material and so proposed to increase the credits offered to 3 in spring 2012.

During this time, there was heightened interest at the university level in revising the university's general-education program, which was being revised to comply with an anticipated new state-mandated general education program. Aware of this, a library faculty representative who sat on the UCC promoted the concept of incorporating an IL element into the university's general-education program to the UCC. This librarian offered as a model the learning outcomes from the ACRL 2000 release of the "Information Literacy Competency Standards for Higher Education." 22 The suggestion - with some modifications - was accepted and formed the basis of a new objective, Information Literacy, which was eventually approved as part 8 of the University's new 9-objective general-education program..$^{23}$

As validating as this inclusion into the proposed general-education program may have been for proponents of information literacy, the knowledge was tempered by the fact that students would be able to graduate without having taken an Objective 8 course, as students could choose to fulfill one of Objectives 7 or 8 of the program. This option was added in response to concerns voiced at the state level over the total number of credits that general education courses would comprise. In this revised form, the general-education program was approved by the UCC and by higher administration to take effect in the $2013 / 2014$ academic year.

The course was first taught in fall 2013 as a three-credit course. One online section was team taught by two librarians, two face-to-face sections were taught by one librarian, 
and another taught one face-to-face section, for a total of four sections. Sections were capped at thirty students and taught in computer laboratories on campus. An example of the syllabus used in this course is at https://sites.google.com/a/isu.edu/jardine/ home/teaching/LLIB\%201115\%20Syllabus\%20Spring\%2017.docx?attredirects=0\&d=1.

At this time, the libraries learned by chance that the School of Nursing had begun to require the library's three-credit course for entry into its traditional Bachelor of Science program. Seeking to know more about this, librarians met with the Nursing School in 2014 to discuss this requirement and learned that students needed help in identifying and evaluating information resources. The school instituted this requirement because its instructors' experiences had been that students were completing assignments without evidence of an understanding of peer-reviewed/scholarly sources. The libraries subsequently learned that the nursing program had also made the course a requirement for its accelerated nursing program in fall 2015. Consequently, the libraries hired its first adjunct instructor in fall 2015 to meet the increased demand; students could enroll in the course for the first time as a summer course the following summer term. This was viewed by the library as a positive indicator of the IL program's success and was favorably viewed by the Nursing School since it helped their students do better in the nursing program.

In fall 2016, that is, the fourth year that had elapsed since the introduction of the three-credit-bearing IL course, the libraries were offering 162 workshops, which demonstrated a degree of ongoing demand. At the same time, demand for the credit-bearing IL courses seemed to be trending upward, including nursing and nonnursing students. The number of sections being offered by fall 2016 had grown to six. This situation created an inherent tension. On the one hand, it appeared that demand for the credit-bearing IL course had continued to grow, and students reported anecdotally that the course made a difference to them; on the other hand, there might be further changes to the general-education program that could potentially reduce the demand for the course.

It seems that the implementation of the three-credit course has had little significant effect on the demand for workshops. Demand for librarians to deliver fall semester workshops for the period 2009-2016 remained fairly stable overall, ranging from 162 to 187 sessions in a semester.

Having reached this point in the development of IL awareness at ISU, librarians decided next to review their situation in the context of their peers and to increase their understanding of how other similar libraries conducted IL programs. They conducted a study in summer 2015 that asked peer institutions to identify how they taught their students IL skills and behaviors.

\section{Methods}

To determine where it stood in the context of its own peers' credit-bearing IL programs, the libraries devised a mixed-method study that included an environmental scan survey followed by optional personal interviews distributed online to staff responsible for coordinating instruction. Survey questions numbered 16 and addressed staff levels, IL activity level, medium of course delivery, and the extent and nature of IL program; it included an opportunity for respondents to make free-text comments. The instrument invited participants to provide contact information if they were willing to talk about their library instruction program in telephone interviews (see appendices 1 and 2).

To determine the scope of participants in the survey, evaluation creators began by looking at ISU's peer institutions, as established by the Idaho SBOE. ${ }^{24}$ All are public, doctoral universities, and enroll between 10,000 to 29,000 students..$^{25}$ The majority of these fourteen institutions are located in the Intermountain West region of the United States, while a few more are scattered across the Midwest or the Pacific Northwest. Three additional institutions were added to the potential evaluation participants, 
because they were identified as aspirational peers, and two were added to the list, because they were the other public universities in the state of Idaho.

Once a list of peer institutions was determined, authors identified the Coordinators of Instruction as contacts for evaluation questions, and an e-mail with a Google Forms evaluation link was sent to them in July 2015. Evaluation recipients were asked to submit responses within two months. At least one follow-up e-mail was sent to potential participants a couple of weeks after the first invitation, encouraging them to complete the survey if they had not already done so. The phone interview period lasted about six weeks during the months of July and August of 2015. The authors chose to conduct an anonymous survey to preserve the integrity of the study, but this did not allow them to compare characteristics of staffing and support of credit-bearing IL. There is a limitation of this study. While some may view the small sample size as a limitation, it can also be seen as an advantage for conducting the type of qualitative environmental scan discussed here. From the list of 18 potential respondents, $14(77 \%)$ completed the questionnaire and 5 volunteered to be interviewed after the survey.

\section{Survey Results}

Responses and comments revealed a clear division in the way that IL programs are being offered. Results showed that 50 percent (7) of all institutions teach credit-bearing IL courses, with the other half teaching one-shot IL workshops only. For the seven institutions that teach credit-bearing IL courses, the majority teach one course; the credits offered per course vary from one to three, and the number of sections offered per year ranges from one to ten (see table 1).

\begin{tabular}{|l|c|c|}
\hline \multicolumn{3}{|c|}{ TABLE 1 } \\
Year and Number of Credits \\
\hline Number of Credit-Bearing IL Courses Taught & $\begin{array}{c}\text { Number of } \\
\text { Institutions }\end{array}$ & Percentage \\
\hline 1 & 4 & $57 \%$ \\
\hline $2-3$ & 1 & $14 \%$ \\
\hline Other & 2 & $29 \%$ \\
\hline Number of Sections Per Academic Year & & \\
\hline $1-5$ & 6 & $86 \%$ \\
\hline $6-10$ & 1 & $14 \%$ \\
\hline Number of Credits Per Course & & \\
\hline 1 & 3 & $44 \%$ \\
\hline $1,2,3$ & 1 & $14 \%$ \\
\hline 1 and 3 & 1 & $14 \%$ \\
\hline $2-3$ & 1 & $14 \%$ \\
\hline 3 & 1 & $14 \%$ \\
\hline
\end{tabular}

As regards the history of these programs, none of the librarians evaluated claimed that teaching credit courses was a recent activity at their libraries. There were two (29\%) libraries that had been teaching these classes for three to five years, and three $(42 \%)$ had been teaching for six to ten years. Two $(29 \%)$ responded that they did not know how long library credit courses had been offered. 
With regard to the method of delivery of credit-bearing IL courses, this group also offers a mix. Of the librarians who teach credit-bearing IL courses, 86 percent reported that they teach these courses via a hybrid method that is comprised of both face-toface and online delivery. Online-only delivery is reported by 14 percent, who reported that they use asynchronous technologies such as Moodle or Blackboard. None of these respondents reported teaching only in face-to-face classrooms (see table 2).

\begin{tabular}{|l|c|c|}
\hline \multicolumn{3}{|c|}{ TABLE 2 } \\
\multicolumn{1}{|c|}{ Delivery Format of Credit-Bearing IL Courses } \\
\hline Delivery Format & $\begin{array}{c}\text { Number } \\
\text { of Respondents }\end{array}$ & Percentage \\
\hline Face to Face only & 0 & $0 \%$ \\
\hline Online only & 1 & $14 \%$ \\
\hline Hybrid & 6 & $86 \%$ \\
\hline
\end{tabular}

Within the peer group used, total library staff size ranged from 24 to 157 and student populations ranged from 10,061 to 29,477 . The evaluation asked how many librarians were involved in credit-bearing instruction. Most responded that they fell into the three to five category for this question. Only one institution employed six to ten librarians to teach IL courses for credit, and two used one to two librarians (see table 3). The extent to which those involved in teaching have additional noninstruction duties was not asked, although this information would also be a factor affecting staff resources available for this activity.

\begin{tabular}{|l|c|c|}
\hline \multicolumn{3}{|c|}{$\begin{array}{c}\text { TABLE 3 } \\
\text { Number of Librarians Teaching Credit-Bearing IL Course and Library Staff } \\
\text { Size }\end{array}$} \\
\hline $\begin{array}{l}\text { Number of Librarians Teaching Credit- } \\
\text { Bearing IL Courses }\end{array}$ & $\begin{array}{c}\text { Number } \\
\text { of Respondents }\end{array}$ & Percentage \\
\hline $\begin{array}{l}1 \text { instructor per session, but the librarians } \\
\text { rotate teaching the course }\end{array}$ & 1 & $14 \%$ \\
\hline $1-2$ & 2 & $29 \%$ \\
\hline $3-5$ & 3 & $43 \%$ \\
\hline $6-10$ & 1 & $14 \%$ \\
\hline Number of All Library Staff & & $57 \%$ \\
\hline $41-50$ & 4 & $29 \%$ \\
\hline $51-60$ & 2 & $14 \%$ \\
\hline $61-70$ & 1 & \\
\hline
\end{tabular}

The evaluation asked participants to describe their courses in relation to the generaleducation program, which reflects the situation at ISU. Only two (29\%) claimed that one of their credit courses fulfilled a general-education requirement. In no case did any library report that its IL credit course was the only course to fulfill a particular generaleducation requirement at its institution. In the comments, a participant noted the current development of a one-credit IL course; "however, we have nowhere near the staffing we need to teach a required information literacy course." Enrollment in IL credit-bearing 
courses is likely to be influenced when the course fulfills a general-education requirement, as suggested by one responder, who commented that students have written on course evaluations that they would never have taken the for-credit IL course if it had not met a general-education requirement. Nevertheless, students add that they are grateful that they did take the course, because of the relevant skills they gained.

Another respondent commented: "We have a developmental IL program that is mandated in 4 general-education courses. We find this works well for our context." This seemed to have been a positive response to a situation that was challenging, as the same librarian also noted that the library had once offered a credit-bearing course for three credits. When university administration directed that the course be adjusted to make it easier for students, the library discontinued the course. In other words, they felt "pressured [...] to 'dumb down' the content." When the authors asked permission to contact them, they said maybe through Skype or by telephone, but they did not provide any contact information. Therefore, there was no follow-up to learn more about this interesting case.

In reporting on the quantity of IL efforts in the form of workshops, 79 percent (11) of respondents reported that their IL instruction programs taught more than 200 workshops in an academic year. Among those teaching fewer than 200 workshops every academic year, 14 percent delivered up to 50 and 7 percent provided between 100 and 200 workshops. Numbers like these suggest that, as a whole, current demand exists for library instruction to support curricular efforts. Unfortunately, university size information, which would provide a useful comparison, cannot be determined from the survey results (see table 4 for complete details).

It was anticipated that increased demand for credit courses would result in fewer requests for one-shot library sessions. More than half of evaluation participants who teach credit-bearing IL courses, however, revealed that the number of one-shot IL workshops offered remained the same. One respondent reported that library workshops taught actually increased after the library started teaching credit-bearing courses (see table 4). Interestingly, one respondent commented at the end of the evaluation that the library staff is "starting to develop some 1 credit courses, however, we have nowhere near the staffing we need to teach a required information literacy course." Obviously, the availability of qualified library instructors limits the amount of instruction that can be offered, regardless of the type of instruction given.

\begin{tabular}{|l|c|c|}
\hline \multicolumn{3}{|c|}{ TABLE 4 } \\
\hline \multicolumn{2}{|c|}{ One-Shot IL Workshops } \\
\hline $\begin{array}{l}\text { Number of One-Shot IL Workshops Taught } \\
\text { per Academic Year }\end{array}$ & $\begin{array}{c}\text { Number } \\
\text { of Respondents }\end{array}$ & Percentage \\
\hline $1-50$ & 2 & $14 \%$ \\
\hline $101-200$ & 1 & $7 \%$ \\
\hline $201-300$ & 4 & $29 \%$ \\
\hline $301-400$ & 3 & $21 \%$ \\
\hline More than 400 & 4 & $29 \%$ \\
\hline $\begin{array}{l}\text { Impact of Credit-Bearing IL Courses on } \\
\text { Demand for One-Shot IL Workshops }\end{array}$ & & \\
\hline Remained the Same & 4 & $57 \%$ \\
\hline Increased & 1 & $14 \%$ \\
\hline Not Sure & 2 & $29 \%$ \\
\hline
\end{tabular}




\section{Results from Personal Interviews}

The questionnaire also asked whether participants would agree to provide additional information about their IL courses and provided space to enter contact information, as well as room to add questions, comments, or suggestions. Five participants agreed to be interviewed, and these interviews took place via telephone and e-mail. Each was asked a set of common questions touching on the history of their library instruction program, enrollment in their credit-bearing courses, impact of credit-bearing courses on the library, overall support from their administration, whether or not other departments required their IL course, involvement in embedded librarianship, and so forth. Some follow-up, detail-oriented questions were tailored to the participants' initial responses to the survey. The comments proved to be a useful part of this evaluation process and revealed common themes, such as the impetus for IL credit-bearing courses - whether they originate with librarians or administrators - and the need to adapt an instruction plan when it does not achieve desired results.

From the interviews, the fact that librarians' instruction efforts were not necessarily self-directed emerged as a common theme. Whether they originated from library administration or from university administration, instruction goals for the credit classes were set by someone other than instruction librarians in many cases. Several interviewees noted that their university or library administrations had asked librarians to teach credit-bearing courses to fulfill student research needs. This demand, however, did not necessarily translate into additional staffing or material support. One interviewee noted that her library director wanted a credit course taught by the librarians. It was not clear how the library would be able to confer credits for the course, so librarians worked with their student support center, which teaches a college-success course and which agreed to "house" the course under its administrative umbrella. Ultimately, however, the campus' curriculum committee did not approve it as a general education course. Because of this, enrollment in the course proved to be spotty: in the first semester, the library offered five sections, while in the following semester it decreased that number to two. Additionally, the library set a minimum enrollment level at eight to nine students for a face-to-face section and five students for an online one.

Another interviewee described a number of library organization and instruction program changes in the last ten years. In response to the provost telling librarians six or seven years earlier that instruction should be their first priority, they collaborated with English faculty to develop a library research class. This one-credit course was designed as a lab to be taken along with the freshman English composition courses and enrolled approximately 200 students per year. During this period, librarians continued to teach workshops across campus.

One interviewee noted that librarians at her library were "encouraged to find strategic opportunities in the curriculum, and to do credit classes if possible." At that time, librarians were offering two credit-bearing courses: one for the English and another for the Chemistry departments. The course supporting English, which was a one-credit course, became a requirement for English majors; the course supporting Chemistry served as an elective. Other credit courses also resulted from individual subject librarians collaborating with their departments, or librarians working with programs such as the graduate school, honors program, or first-year seminar program. For example, a data management course also resulted from a librarian's work with the graduate school. When she was asked about institutional and administrative support, she echoed what others had said: "There is general agreement that it is important, but this does not always translate to material support."

In contrast, one of the interviewees had the opposite experience, reporting that "Librarians worked to teach a credit-bearing course, observing that the faculty on 
campus wanted them to teach a credit course. They received approval to teach an information-literacy course; however, about this time a new library dean put an end to this initiative." She explained how the library dean felt that the course belonged to the university's School of Library and Information Science (SLIS) and that the library was not a revenue-generating college. It was reported that other colleagues had left during the previous year, so buy-in and momentum with this initiative may have floundered for these reasons as well. Since faculty were at loggerheads over the issue of tenure with the then-current dean, the credit-bearing course did not get off the ground at this institution.

Librarians' abilities to adapt when IL instruction efforts such as credit courses did not work proved to be another theme that emerged from the interviews. Interviewees encountered different challenges with each method of instruction, so they adapted to individual circumstances. At least one institution succeeded in setting up credit-bearing instruction that was required of all students. The librarians teaching these courses encountered negative student attitudes that adversely affected their satisfaction with teaching the course, so they developed a model that embedded library instruction into an already required foundational course. The librarians found these university foundations courses, which reached 3,000 students each year, to be more satisfying. This reflects the adaptability of these academic librarians to their own local circumstances. Even so, due to the volume of library instruction attached to the required course and a limited number of library instructors, they had to stop teaching on-demand workshops for the English composition courses.

One interviewee noted that teaching this credit-bearing course did not always result in positive feelings among the librarians. Because teaching the course had been requested by library administration, librarians did not feel ownership or interest in the course. Librarians take turns teaching the course, and it sounded as if the willingness of some to do so is not necessarily very high. Some want to teach credit courses, but others do not, and uncertainty remains about whether or not their credit-bearing course will continue. When asked about the impact of their credit course, the interviewee responded: “This is the touchy question. It has an impact, and it's not always a positive one." Namely, it increased the library faculty's workload and did not come organically from the faculty members themselves. But the experiences of the interviewees were not all like this interviewee's: other librarians enjoyed teaching credit-bearing courses, having found that it increases their credibility with faculty peers on campus. The teaching also provided more opportunities for professional development and increased interaction with students over a sustained period.

While evaluation respondents identified varied IL programs, it was evident that librarians were dedicated to the goal of increasing IL skills among college students in the face of limited resources. One interviewee noted that:

"Initially, it was seen as an efficient way to get a required information literacy component into the disciplinary courses (to build on first-year composition). When the number of teaching librarians was reduced, our ability to do it became limited. Now, the focus is more on skills and concepts that are missing from the rest of the curriculum - but which are essential to student success."

Another interviewee expressed enthusiasm and conviction in the importance of library instruction. She felt that teaching for credit was an "excellent idea." As further justification, she said: "Many assume that students learn all this stuff in their English class." In fact, this librarian explained that, when a faculty instructor became frustrated with student performance on an assignment, student feedback indicated that they 
needed additional help. This led the instructor to pursue the idea of embedding an IL component in the course. Other faculty also lamented the quality of student research skills and started requesting help from librarians. This interviewee shared an enthusiasm for teaching students IL skills. She came to the library with an education background and found it energizing to interact with students. Embedding herself in courses gives her more opportunity to interact with students, which she said she really enjoys.

\section{Discussion}

The survey revealed that 50 percent of this group of peers is delivering credit-bearing IL, which is a level of participation higher than has been reported in any of the largeror smaller-scale studies. The most common delivery method blends face-to-face with online delivery, which is not surprising, and face-to-face-only delivery has disappeared from this group. The number of libraries whose credit-bearing IL programs bear a relationship to some aspect of general education is low at 29 percent and may reflect the relatively low level of success that librarians have experienced in placing IL among their institutions' priorities. The amount of non-credit-bearing IL was reported as having been unaffected by the introduction/existence of credit-bearing IL by one-half of the respondents who offer credit-bearing IL; in one case, the amount increased. This is perhaps the most revealing of the survey results, for it suggests a significant need for both types of IL.

The survey also revealed a heartening display of professional integrity, as evidenced by the "dumbing down" comment, as discussed in the Survey Results section. This situation indicates that not only did the librarians at that institution refuse to lower their professional standards, but that they adapted to this apparently negative development and moved forward by integrating their library instruction into several general-education courses, which also became mandatory.

The two themes - that credit-bearing IL course delivery is not usually self-directed and the extent of flexibility exhibited by interviewees - that emerged from the interviews provided useful depth and nuance to this scan of peer experiences. They illustrated that the IL programs developed individually and were the result of the blending of an embodiment of the service ethic that is inherent in the academic library profession with and in response to local priorities and resources. The significance of this illustration is that it provides reflective topics for libraries that are assessing their own IL credit-bearing courses.

Another positive interview comment addressed why libraries may want to offer IL credit-bearing courses:

"I do think that librarians who want to teach credit courses should be encouraged to do so for a number of reasons - it gives a much more authentic perspective on the needs and concerns of teaching faculty, it provides our librarians (who no longer work at the desk) with their only opportunity to interact with students in a sustained way; and it is, quite simply, more satisfying for many of the librarians-it's a weapon against burnout and cynicism."

These interview results provided ideas and strengthened the commitment to creditbearing IL instruction at ISU. For example, the library has increased the number of online sections offered in response to increased demand for that delivery format. Conducting the survey reinforced the need for the instruction program to be flexible and to make adaptations to the program. One change was that the department worked on developing research tutorials with the idea to meet the students' research needs in the English composition courses and to replace face-to-face, first-semester workshops. 
Additionally, ISU libraries have developed a contingency plan in case the general education program is altered and Objective 8: Information Literacy is removed from the curriculum, or in case of unforeseen developments. Results of this study yielded multiple options that increased ISU Libraries' potential instruction repertoire, such as embedded librarianship, reducing the number of credits in the IL course, and filling gaps in the curriculum by focusing on research concepts and skills in upper-division courses.

\section{Conclusion}

As a result of this study, the ISU Libraries have learned where its peer group falls with regard to the proportion of member libraries who participate in credit-bearing IL delivery. This is an active group, as the participation level (50\%) is above the reported highs ( $45 \%$ ) from other such groups in the United States. How the ISU Libraries perform in other measures relative to their peers have helped them to determine future strategies and to participate fruitfully in discussions of library priorities. In its method of delivery, ISU Libraries fall within the vast majority of 86 percent by offering a mix of online and face-to-face delivery. In terms of quantity of sections offered, they fall at the high end of the number of sections taught per semester and have recently increased that by 1 due to demand. In terms of overall staff size, they are the smallest among their peers. The nature of this level of activity may be attributable to many things - staff determination, degree of administrative support, and perhaps more, and it helps the ISU Libraries maintain relevance within the university environment.

Although these results look good for ISU's instruction program, they have also raised questions for instruction staff. Within the context of peers' activities, instruction staff may be doing more than available resources provide for. This may require that library administration look into adjusting staff workloads librarywide, since, at present, instruction staff are responsible for more than instruction-they also perform collection development and participate in committee and service efforts. Library administration may also need to acknowledge that current demand cannot be met with existing staff levels.

The need to teach students IL skills remains. William Badke writes: “The most glaring error in higher education's current struggle for relevance is our blindness to the fact that our students do not know how to do research, and we are not doing enough to help them. ${ }^{26}$ Whether the academic library community is, in fact, doing enough to help students do research in higher education was a motivating force for this study, and answering it will require the efforts of all instruction librarians, as well as further study. Instruction librarians at ISU Libraries are better equipped now to engage in such a discussion. At the same time, it seems clear that next steps need to include a study to measure the effectiveness of the instruction program and, ideally, its impact on student retention. 


\section{Appendix 1: Survey Questions}

\section{Information Literacy and Instruction Survey}

The Idaho State University Libraries' instruction program has evolved from teaching mainly one-shot instruction sessions to teaching three-credit courses while continuing to teach many on-demand instruction sessions. The purpose of this survey is to find out how library instruction programs have adapted to meet institutional and societal needs at ISU's peer institutions.

This survey (16 questions) includes multiple choice questions and an invitation to share preferred contact information for a follow-up interview. It does ask for estimates of instruction numbers, particularly in the areas of instruction sessions, credit courses, and staff size. I estimate that it takes from 5-10 minutes to complete this survey.

1. How many credit courses are taught by your library?

$\square \quad$ None, but we teach a lot of library instruction sessions as requested.

$\square \quad$ One information-literacy course directed at lower-division undergraduate students.

$\square \quad$ Two to three credit courses for lower-division and/or upper division students.

$\square \quad$ Other:

2. How many credits are offered for courses taught by your library? Mark all that apply.
1
ㄴ 2
$\square 3$
$\square \quad$ Not applicable
$\square$ Other:

3. How many total sections of three-credit courses per academic year does your library teach?
1-2
3-5
ㅁ 6-10
11-15
16-20
․ More than 20
$\square \quad$ Not applicable

4. How many total sections of credit courses per academic year does your library teach?

$\begin{array}{ll}\square & 1-2 \\ \square & 3-5 \\ \square & 6-10 \\ \square & 11-15 \\ \square & 16-20 \\ \square & 21-25 \\ \square & 26-30 \\ \square & \text { More than 30 } \\ \square & \text { Not applicable }\end{array}$


5. In which medium do you deliver these credit courses? Mark all answers that apply. 口 $\quad$ Face-to-face in a classroom

$\square \quad$ Asynchronous online with recorded videos, instructions, electronic course materials, and lectures

$\square \quad$ Synchronous course broadcasted in real time

$\square \quad$ Course Management System such as Blackboard or Moodle

$\square \quad$ Hybrid

$\square \quad$ Distance transmission

$\square \quad$ Not applicable

$\square$ Other:

6. How many library instructors teach these library, information-literacy credit courses?
1-2
$3-5$
6-10
$\quad$ More than 10
$\square \quad$ Not applicable
口 Other:

7. How many librarians work at your library?
1-9
10-15
16-20
21-25
26-30
31-35
$\quad 36-40$
$\quad$ More than 40
I do not know
口 Other:

8. How large is the library staff, including librarians, assistants, and administrators at your library?
$\quad 0-20$
21-30
$\quad 31-40$
$\quad 41-50$
51-60
$\quad 61-70$
$\quad$ More than 70
I do not know

9. How long have these credit courses been taught?
1-2 years
$\square \quad 3-5$ years
$6-10$ years
11-15 years
$\square \quad$ More than 15 years
․ I do not know
$\square \quad$ Not applicable 
10. Do any of your credit courses fulfill a general education requirement?

$\square \quad$ Yes

$\square \quad$ No

$\square \quad$ Not applicable

11. If one or more of your library, information-literacy courses fulfills a general education requirement, is it the only course at your institution that fulfills the general education goal?

$\square \quad$ Yes

$\square \quad \mathrm{No}$

$\square \quad$ Not applicable

12. Approximately how many non-credit workshops or library instruction sessions are offered by your library each academic year?
$\quad 0-50$
51-100
101-200
201-300
301-400
More than 400
․ I do not know
$\square \quad$ Not applicable

13. If you teach credit courses, would you say that your library workshops or instruction sessions have as a result of the credit courses?

$\begin{array}{ll}\square & \text { decreased } \\ \square & \text { increased } \\ \square & \text { stayed the same } \\ \square & \text { It is uncertain } \\ \square & \text { Not applicable. We do not teach credit-bearing courses. }\end{array}$

14. Would you be willing to talk about library instruction courses over the phone, with Skype technology, face to face, or through some other medium? If "yes" or "maybe," please indicate preference of communication method in the "Other" box.
$\square \quad$ Yes
$\square \quad \mathrm{No}$
$\square \quad$ Maybe
$\square$ Other:

15. If you are willing to talk about library instruction courses, would you please provide your name and preferred contact information below?

$\square \quad$ Please share your name, plus your telephone number, e-mail address, or Skype username.

16. If you would like to add any comments, questions, or suggestions, please add them here.

\section{Appendix 2: Follow-up Interview Questions}

- What is the history of your library instruction program? 
$\square \quad$ The survey you completed indicates you have been teaching credit courses _ years. How did you get the library courses accepted and approved?

$\square \quad$ Why did your library decide to teach or develop credit courses? What were the intentions?

- How many students on average enroll in your credit courses each year?

- How has demand for these courses fluctuated?

- How would you explain the change or steadiness in enrollment numbers?

- What kind of impact has teaching credit courses had on the library?

- Are there any departments or programs that require the library's informationliteracy, research course for their students? Which ones?

- Are librarians at your university embedded or integrated into courses? If so, would you please describe here the degree of involvement and how this works?

- What support has your university given for your credit courses?

- What support has your university or library administration given for library instruction in general?

- What are the expectations for library instruction on librarians at your institution?

- Does your library instruction program have a set of policies and procedures? Would you be willing and able to share this document?

\section{Notes}

1. Di Su, Library Instruction Design: Learning from Google and Apple (Oxford: Chandos Publishing, 2014), 31.

2. ACRL's Instruction Section, Analyzing Your Instructional Environment: A Workbook, available online at http://acrl.ala.org/IS/instruction-tools-resources-2/higher-education-environment/ analyzing-your-instructional-environmen/ [accessed 14 June 2017].

3. William Badke, "A Rationale for Information Literacy as a Credit-Bearing Discipline," Journal of Information Literacy 2, no. 1 (2008): 1-22, doi:10.11645/2.1.42.

4. Best Practices for Credit-Bearing Information Literacy Courses, ed. Christopher Vance Hollister (Chicago: Association of College and Research Libraries, 2010).

5. Jennifer Mayer and Melissa Bowles-Terry, "Engagement and Assessment in a Credit-Bearing Information Literacy Course," Reference Services Review 41, no. 1 (2013): 62-79.

6. Paul L. Hrycaj, "An Analysis of Online Syllabi for Credit-Bearing Library Skills Courses," College \& Research Libraries 67, no. 6 (2006): 525-35, doi:10.5860/crl.67.6.525.

7. Simone L. Yearwood, Nancy M. Foasberg, and Kenneth D. Rosenberg, "A Survey of Librarian Perceptions of Information Literacy Techniques," Communications in Information Literacy 9, no. 2 (2015): 186-97.

8. Nadine Cohen et al., "A Survey of Information Literacy Credit Courses in US Academic Libraries: Prevalence and Characteristics," Reference Services Review 44, no. 4 (2016): 564-82, doi:10.1108/RSR-03-2016-0021.

9. Margaret Burke, "Academic Libraries and the Credit-Bearing Class," Communications in Information Literacy 5, no. 2 (2012): 156-73, doi:10.15760/comminfolit.2012.5.2.110.

10. Erin L. Davis, Kacy Lundstrom, and Pamela N. Martin, "Librarian Perceptions and Information Literacy Instruction Models," Reference Services Review 39, no. 4 (2011): 686-702, doi:10.1108/00907321111186695.

11. Mary Bolner Butterfield, "Project LOEX Means Library Orientation Exchange," RQ (1973): 39-42, https://www.jstor.org/stable/25825576.

12. Carolyn Kirkendall, "Library User Education: Current Practices and Trends," Library Trends 29, no. 1 (1980): 29-37, https://www.ideals.illinois.edu/bitstream/handle/2142/7122/librarytrendsv29i1d_opt.pdf?sequence=1.

13. Teresa B. Mensching, "Trends in Bibliographic Instruction in the 1980s: A Comparison of Data from Two Surveys," Research Strategies 7, no. 1 (1989): 4-13.

14. Linda Shirato and Joseph Badics, "Library Instruction in the 1990s: A Comparison with Trends in Two Earlier LOEX Surveys," Research Strategies 15, no. 4 (1997): 223-37.

15. Sue F. Phelps, Heidi Senior, and Karen R.R. Diller, "Learning from Each Other: A Report on Information Literacy Programs at Orbis Cascade Alliance Libraries," Collaborative Librarianship 3, no. 3 (2011): 3, https://digitalcommons.du.edu/collaborativelibrarianship/vol3/iss3/3/. 
16. Laura Windsor, "The Current Status of Bibliographic Instruction in Academic Libraries: A Survey," Colorado Libraries 14 (1988): 22-24.

17. Barbara Wittkopf, "A Look at the State of BI Credit Courses in the ARL-Member Libraries," Research Strategies 9, no. 4 (1991): 162-63.

18. Susan Janney, "Bibliographic Instruction at Learning Resources Centers in North Carolina," North Carolina Libraries 44 (1986): 16-22.

19. Jessica Hutchings and Malia Willey, "Resilience and Redirection: Information Literacy in Louisiana Higher Education," portal: Libraries and the Academy 14, no. 2 (2014): 239-53, doi:10.1353/ pla.2014.0006.

20. Otis Chadley and Jacquelyn Gavryck, "Bibliographic Instruction Trends in Research Libraries," Research Strategies 7, no. 3 (1989): 106-13.

21. ISU's Libraries Instructional Services Mission, available online at http://isu.libguides.com/ instruction/whatwedo [accessed 6 August 2018].

22. ACRL's Information Literacy Competency Standards for Higher Education, available online at http://isu.libguides.com/ld.php?content_id=33154477 [accessed 6 August 2018].

23. ISU's General Education Objectives and Learning Outcomes, available online at https:// www.isu.edu/gerc/gen-ed-objectives-and-courses/ [accessed 6 August 2018].

24. ISU's Institutional and Aspirational Peers, available online at http://www.isu.edu/media/ libraries/academic-affairs/Institutional-and-Aspirational-Peers_09.14-(1).docx [accessed 6 August 2018].

25. Carnegie Classification of Institutions of Higher Education, available online at http:// carnegieclassifications.iu.edu/ [accessed 6 August 2018].

26. William Badke, Teaching Research Processes: The Faculty Role in the Development of Skilled Student Researchers (Witney, U.K.: Chandos Publishing, 2012): xi. 